\title{
THE INABILITY OF DIBUTYRYL ADENOSINE 3',5'-MONOPHOSPHATE TO INDUCE THE DECIDUAL REACTION IN INTACT PSEUDOPREGNANT MICE
}

\author{
F. T. G. WEBB* \\ Department of Zoology, South Parks Road, Oxford OX1 3PS
}

(Received 25th Fuly 1974)

The technique for assessing the ability of a compound to initiate the decidual response is simple and conclusive. It involves introducing the compound in solution into the uterine lumen of an intact rat or mouse during the 'sensitive period' of pseudopregnancy (Finn \& Keen, 1963; Hetherington, 1968). This technique was used to compare the ability of arachis oil, phosphate-buffered saline (PBS; Dulbecco \& Vogt, 1954) and dibutyryl adenosine 3',5'-monophosphate (dibutyryl cyclic AMP-dcAMP) to initiate the decidual response after injection into the uterine lumen of the mouse at various times on the 4th day of pseudopregnancy.

Pseudopregnancy was induced in A2G mice from a closed colony in the Department, by mating them with vasectomized males of the same strain, vaginal plugs being taken to indicate the lst day of pseudopregnancy. Animals were allocated to fifteen groups, each comprising four to seven mice. On the 4th day at $09.30,12.30$ or 15.30 hours, a single intraluminal injection (by way of the uterotubal junction) of $0.02 \mathrm{ml}$ arachis oil, PBS or a solution of dcAMP (Sigma) in PBS was given. Three concentrations of dcAMP were used: 1.25 $\mathrm{mm}, 2.5 \mathrm{~mm}$ and $3.75 \mathrm{~mm}$. At autopsy on the 7 th day, the horns were excised, divided at the cervix and weighed separately before being fixed in Bouin's solution for subsequent histological examination.

A decidual response was observed in six of seven horns treated with arachis oil at 12.00 hours and one of five horns receiving oil at 09.30 hours. The mean weight of the horns with deciduomata was $111.0 \mathrm{mg}$, which was significantly different from the mean weight of the contralateral horns without deciduomata $(46.5 \mathrm{mg})$. There was no evidence of a decidual reaction in any of the mice receiving oil at 15.30 hours. The PBS was unable to induce the response, a finding which agrees with those of Finn (1965). None of the three concentrations of dcAMP at any of the times of injection was able to induce deciduomata. The mean weights of the horns injected with dcAMP did not differ significantly from those of the respective contralateral horns, and varied between $29.6 \mathrm{mg}$ and $42.5 \mathrm{mg}$. It was concluded that dcAMP was unable to induce the decidual response in these mice.

Histamine has been suggested as the stimulus for the decidual response in rodents (Shelesnyak, 1960). This theory has not won universal acceptance (see

* Present address: Physiological Laboratory, Downing Street, Cambridge CB2 3EG. 
Finn, 1971) and was later modified by Shelesnyak, Marcus \& Lindner (1970) to give histamine the rôle of mediator in the action of the inducing stimulus. The exact nature of the stimulus remains unknown (McLaren, 1969, 1970). Histamine is known to exert its action by stimulation of adenyl cyclase (Rall \& Kakiuchi, 1966) and, in common with other compounds whose action is mediated by this enzyme, it should be possible to mimic the effects of histamine by administration of exogenous cyclic AMP (Robison, Butcher \& Sutherland, 1971). The inability of the dibutyryl analogue of cyclic AMP, which is known to be more potent than the pure form (Posternak, Sutherland \& Henion, 1962), to initiate the decidual response suggests that histamine is not involved in the response either as a stimulus or as a mediator of the stimulus. This result also suggests that whatever is the stimulus, it is unlikely that it exerts its effect by stimulating adenyl cyclase in uterine cells. Leroy, Vansande, Shetgen \& Brasseur (1974) have reported that dcAMP injected intraluminally does not induce the decidual response in mice which have been primed with hormones after long-term ovariectomy. Some deciduomata were obtained after intraperitoneal injection of dcAMP and theophylline, but the dose of the nucleotide, and mortality of the mice, was extremely high.

This work was carried out during the tenure of a NATO Research Studentship from the Science Research Council. The author is indebted to Dr Christopher Graham for his advice and encouragement.

\section{REFERENCES}

Dulbecco, R. \& VoGt, M. (1954) Plaque formation and isolation of pure lines with poliomyelitis virus. J. $\exp$. Med. 99, 167-182.

FINN, C. A. (1965) Oestrogen and the decidual reaction of implantation in mice. F. Endocr. 32, 223-229.

Fins, G. A. (1971) Biology of decidual cells. Adv. Reprod. Physiol. 5, 1-26.

FinN, G. A. \& KrEN, P. M. (1963) The induction of deciduomata in the rat. F. Embryol. exp. Morph. 11, $673-682$.

Hetherington, G. M. (1968) The development of deciduomata induced by two non-traumatic methods in the mouse. F. Reprod. Fert. 17, 391-393.

Leroy, F., Vansande, J., Shetgen, G. \& Brasseur, D. (1974) Cyclic AMP and the triggering of the decidual reaction. F. Reprod. Fert. 39, 207-211.

MaLAREN, A. (1969) Stimulus and response during early pregnancy in the mouse. Nature, Lond. 221, 739-741.

MaLAREN, A. (1970) Early embryo-endometrial relationships. In Ovo-implantation, Human Gonadotropins and Prolactin, pp. 18-37. Eds. P. O. Hubinont, F. Leroy, C. Robyn and P. Leleux. Karger, Basel.

Posternak, Th., Sutherland, E. W. \& Henion, W. F. (1962) Derivatives of cyclic 3',5'-adenosine monophosphate. Biochim. biophys. Acta, 65, 558-560.

Rall, T. W. \& KAKIUCHI, S. (1966) The influence of certain neurohormones and drugs on the accumulation of cyclic 3',5'-AMP in brain tissue. In Molecular Basis of Some Aspects of Mental Activity, Vol. 1, pp. 417-427. Ed. O. Walaas. Academic Press, New York.

Robison, G. A., Butcher, R. W. \& Sutherland, E. W. (1971) Cyclic AMP. Academic Press, New York. ShelesNyak, M. C. (1960) Nidation of the fertilised ovum. Endeavour, 19, 81-86.

Shelesnyak, M. C., Marcus, G. J. \& Lindner, H. R. (1970) Determinants of the decidual reaction. In Ovo-implantation, Human Gonadotropins and Prolactin, pp. 118-129. Eds. P. O. Hubinont, F. Leroy, G. Robyn and P. Leleux. Karger, Basel. 